\title{
Cognitive Linguistic Models for Analyzing Characterization in a Parable: Luke 10:25-37 The Compassionate Samaritan
}

\author{
Bonnie Howe \\ New College Berkeley, Berkeley, CA, USA \\ bghowe2@gmail.com \\ Eve Sweetser \\ UC Berkeley, Berkeley, CA, USA \\ sweetser@berkeley.edu
}

\begin{abstract}
This study employs an array of cognitive linguistic (CL) models to reveal some of the details in how contemporary readers understand and interpret characters in a New Testament parable, the one often tagged "The Good Samaritan." It also uses cognitive narrative analysis to explore how Luke constructs and develops the dialog partners in the pericope and the characters in the parable. The larger goal is to use CL to reveal some of the ways in which meanings are evoked, constructed, constrained and opened up. The parable is embedded in a larger narrative and immediate co-text, its characters selected from the stock of Lukan personae. The study explains how narrative spaces are built up; how characters serve as anchors and links to the larger narrative; and how viewpoint shifts proliferate as the story unfolds.

The Lukan narrator makes Jesus' viewpoint clear: “Do this, and you will live!" Readers are implicitly invited to identify with the compassionate character of the parable and emulate him. But the opening question and closing dialog shape the parable's point, expanding its trajectory beyond mere moral rule revision or definitions of "neighbor" or even of "good" character. This parable allows readers to imagine with Luke a way of life lived in the light of the new epoch Jesus is announcing and inaugurating.
\end{abstract}




\section{Keywords}

conceptual blends - conceptual Ground - embodied cognition - embodied simulation - mental spaces - metonymy - narrative anchors - semantic frames

\section{Orientation: Focal Text, Methods, and Aims}

Centerstage, Jesus and the Twelve share a private moment. Outside the spotlight, the seventy-two recently-returned missionaries are gathered. Now a Torah scholar stands, confronting Jesus: "Teacher, what must I do to inherit everlasting life?" (Luke 10:25) What must I do? is the question shaping this

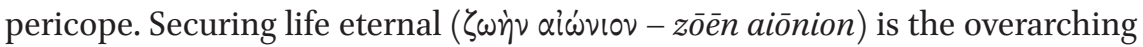
concern.

Luke reports a tight, perhaps tense exchange between two main characters Jesus and a nomikos (Torah scholar; lawyer). The dialog partners come quickly to a new question: "And who is my neighbor?" Everyone listens to the parable Jesus tells in response. And everyone hears the Teacher's final question: "Who then, acted as a neighbor?" Everyone hears Jesus' clear imperative: "Go and do likewise!" What must we do? becomes the question challenging Luke's readers.

This study uses cognitive linguistic (CL) tools to investigate how characterization is accomplished in this short but profound narrative, Luke 10:25-37. We have met the dialog partners, but the parable characters are also in view; Jesus will use them to engage the Torah scholar and refocus the conversation. Here is the guiding question: How do 21st century readers construe these New Testament characters and use them to understand and respond to the parable and the dialog?

CL methods can shed light on the dynamics of characterization within the Lukan text, but also can help us understand the potential impact of characterization and storytelling on individuals and reading communities. ${ }^{1}$ Readers' primary access to these texts is via their own reading and study practices, in their own reading circles - scholarly or not, secular or not. In any case, there are many challenges. The text is over two thousand years old, written in Koiné

\footnotetext{
1 Barbara Dancygier points to Michael Tomasello's model for tracking emergence of fiction as forms of sharing information and in particular, "attempts to establish social norms through storytelling" (B. Dancygier, The Language of Stories: A Cognitive Approach [Cambridge and New York: Cambridge University Press, 2012], p. 19); and see M. Tomasello, The Cultural Origins of Human Cognition, (Cambridge, MA: Harvard University Press, 1999). Also see D. Herman, "Narratology as a Cognitive Science," Image and Narrative 1 (2000), http://www. imageandnarrative.be/inarchive/narratology/davidherman.htm
} 
Greek, demanding cross-linguistic and cross-cultural work. Yet the potential payoff is high - for nuanced understanding of NT narrative and parable; for understanding characterization in Luke's Gospel; for speculation about how reading and interpretation work; and for exploring the mechanisms, mysteries, and the power of "imagining the world that Scripture imagines."

\section{Cognitive Linguistic Toolkit}

Embodied cognition and its links to language is our methodological starting point. Important tools are mental spaces and the idea of the conceptual Ground crucial for any human communication. The study will look at how mental spaces are networked and blended, and how semantic frames structure them. We will consider how each character is associated with frames that display and organize categories, and each projects a viewpoint, altering the story as elements belonging to particular frames are activated. Crucially, mental space and frame evocation prompts embodied simulation, as readers imagine what it would be like to experience both the dialog and what happens in the parable. ${ }^{3}$ These are the main CL models this study uses.

\section{Mental Spaces and Shared Conceptual Ground}

As we think and use language - talk, write, and read - our minds constantly activate and link bits of cognitive structure. Cognitive linguists call these activations mental spaces. ${ }^{4}$ Spaces are set up in working memory; they proliferate, link and de-couple, in real time. Mental spaces can be networked to represent real or imagined scenarios that people use to make sense of everyday life and interactions, as well as when they compose or read (or hear) a story. Our focal text bears evidence of mental space blending, and readers use blending when they interpret this text. Blending can prompt global insight and catalyze shifts

2 L.T. Johnson, "Imagining the World Scripture Imagines," Modern Theology 14:2 (April 1998), pp. $165^{-180 .}$

3 B.K. Bergen explains the embodied simulation hypothesis and discusses its origins in Louder than Words: The New Science of How the Mind Makes Meaning (New York: Basic Books, 2012), pp. 10-17.

4 "Mental spaces are partial structures that proliferate when we think and talk, allowing a fine-grained partitioning of our discourse and knowledge structures" (G. Fauconnier and M. Turner, The Way We Think: Conceptual Blending and the Mind's Hidden Complexities [New York: Basic Books, 2002], p. 11). 
in readers' perceptions, moral landscapes and behavioral repertoires, even impacting their own character.

How does an author achieve characterization? How do modern readers make sense of a two-thousand-year-old parable and construe its characters? CL holds that authors and readers find (or imagine) common Ground. This common conceptual Ground is the result of shared human bodily experience and shared cultural frames. Luke does not fill in all the details of the story; he relies on the basic communicative spaces of the Ground to carry readers through to understanding. Narrative, like all other human communication, is built on this Ground. ${ }^{5}$

The Ground need not be evoked via words in a given text; instead, the Ground comprises the basic communicative context. What kind of conceptual Ground is "just there" for readers of this pericope? Whenever people write or read something, we do not have to re-establish the basics of the human visual field or the range of human hearing. When Luke's Jesus speaks to the Torah scholar, readers hear those voices immediately. They run that simulation without consciously willing it, via the Ground. Physical experiential common Grounding gives readers access to the experiential frames at work in the pericope: talking, walking, pouring oil, lifting a heavy load, thirst and pain. There is also the Ground in shared cultural frames of conversation and a polite but agonistic exchange. Jesus and the Torah scholar do not have to negotiate the parameters of 1st century proto-rabbinical dialog before they have their conversation, nor does the Lukan narrator stop to explain those parameters to his readers. Similarly, the participants in the parable act on shared, common Ground with regard to hospitality and travel customs. But transcultural Ground is also available to enable communication; modern readers share considerable

5 The Ground (capitalized when it names a mental space) is the basic structure of communicative mental space, in relation to which communication is done and interpreted. In CL, lower-case "grounding" refers to the phenomenon, the active relationship between the Ground and the set of mental spaces in a network. That is, the Ground provides grounding for networks of mental spaces. Dancygier says the Ground "also provides access to shared cultural and conceptual framing, so that the interlocutors can assume access to culturally salient concepts." The Ground includes "the immediate surroundings, the presence of the speaker and the hearer, shared knowledge, shared visual and aural field, shared understanding of bodily experience, and last but not least, the surrounding discourse context. The common Ground makes various aspects of communication possible, since meaning can be derived from ostensive aspects of communication, from objects manifest in the environment, and from the interlocutors' body language, gesture, facial expressions, tone of voice, et cetera" (Dancygier, Language of Stories, p. 19). See also S. Coulson and T. Oakley (eds.), "Conceptual Blending," Journal of Pragmatics 37 (2005); A. Verhagen, Constructions of Intersubjectivity: Discourse, Syntax, and Cognition (Oxford: Oxford University Press, 2005). 
common Ground with ancient characters: we know what it is to travel down a road, to be wounded, to encounter a needy stranger. Narrative characterization, then, relies on the most basic kind of common Ground.

Without this Ground, character development would not happen, particularly in a narrative like this one, which is very parsimonious about mental states. The storyteller, Jesus, does not reveal why the priest and Levite act the way they do, though he does say the Samaritan was compassionate. He does not reveal what the innkeeper did, or what the wounded man's response was. There are no details about who the bandits were or their motives. The cryptic designation of the victim as $\alpha \dot{v} \theta \rho \omega \pi$ ó $\tau \iota \zeta$ - anthrōpos tis - "somebody," "some person," "a man," or "a human being"- forces readers to fill in the profile, to imagine the contours of that character. Nevertheless, the Ground allows that to happen. ${ }^{6}$ Only via the semantic frames and the cultural setting can readers construct characters and their motives. In reading the parable, we're necessarily constructing characters' actions, goals, and moral states by imagining how people in those situational frames would act. Inasmuch as those frames are part of a shared Ground, readers will share constructions of the characters, and interpretation of the texts.

\section{Gaps, Ground and Gut Responses}

However, it is a basic principle of cognitive linguistics that there is no direct mind-reading going on when we read texts. A writer has only his or her imagined construction of the cognitive states of readers, and a reader has only an imagined construction of the writer's meaning. An important aspect of communication is that it is always partial; it would be impossible to specify every aspect of a situational experience in full detail in a written text. So unspecified aspects of the meaning are necessarily filled in from the Ground. An important aspect of the Ground in communication is the assumption that it will not be fully shared: inevitably there will be confusion, ambiguity, and gaps that conversation partners or readers have to fill in from their different (though perhaps similar or overlapping) Base Spaces (defined below).

6 Geography also functions as shared Ground. Joel B. Green notes that "[Jesus] is now on the way to the center of the Jewish world, Jerusalem, which, with its temple, had come to perpetuate and determine the boundaries of acceptable social intercourse .... This, of course, reminds us that geographical markers are not neutral or objective, but are social products that reflect and configure ways of understanding the world" (J.B. Green, The Gospel of Luke [NICNT; Grand Rapids: Eerdmans, 1997], pp. 426-427, n. 99). 
Readers are thus assumed to do significant work in this communicative endeavor. Engaged readers will be drawn into the scenario and begin to feel (or not to feel) compassion for the assault victim and dislike for the priest and Levite - or identification with them and even defensiveness on their behalf. Some readers may recognize themselves in this behavior. ${ }^{7}$ Barbara Dancygier observes:

Any narrative form assumes the readers' or listeners' ability to feel for the characters and interpret the events from the characters' point of view - to feel sympathy, envy, disgust, anger, et cetera. While some of these emotional responses may be complex, or even conflicted, they are better explained through our ability to feel empathy, and also to attribute emotional meaning to linguistic expressions - even simple experiential concepts such as up (alert, conscious, confident, in a good mood) or down (tired, inactive, sick, unconscious, dejected). ${ }^{8}$

We will have more to say about cognitive linguistic construals of reader responses when we discuss narrative uptake. The present point is that the pericope depends upon the human ability to feel for characters, a crucial aspect of the Ground. Along with general cultural knowledge, the Ground implicitly presents us with a complex network of mental spaces. No discourse lacks such Ground. This is crucial cognitive input that we get "for free," in a way. But that doesn't mean it is without value; far from it. Without this basic Ground, no communication happens.

\section{Mental Space Networks}

Gilles Fauconnier and Mark Turner made it clear that meaning resides not in individual words or spaces but in the network of activated mental spaces that an experience evokes. ${ }^{9}$ To understand this dialog and the parable, readers place the narrative events and characters in a network of spaces, including the imagined writer, Luke, the Jesus who teaches here, and his narrative audience,

7 A response in the spirit of Rom. 7:15-19 could be evoked. Ancient writers recognized that people often act contrary to their own maxims: cf. Ovid, Metam. 7,19-21; Seneca, Med. 989-992; Euripides, Hipp. 377-383, 6o4-6o5; Med. 1077-108o; Plato, Prot. 352b.

8 Dancygier, Language of Stories, p. 29.

9 Fauconnier and Turner, The Way We Think, pp. 40-41; 119-120. Mental space blending is also networking. 
his disciples. The parable Jesus tells becomes a source story that can be projected onto many target situations..$^{10}$ If this story were told on its own, or even if it occurred in a recently recovered "lost" gospel text, outside the frame of Luke's presentation of the teaching of Jesus, it could not have the same meaning. The communicative space network surrounding it passes cognitive content upwards to the (imagined) Lukan narratorial viewpoint, and to the (intended or imagined) readers who find the text interesting and important because of Jesus' role in Luke and - potentially - in their reading communities. This is upwards float in the mental space network. ${ }^{11}$ The fact that Luke's character Jesus said these words gives the broader text value.

\section{Semantic Frames}

The surrounding scene that gives rise to this parable-telling is a framing event of teaching. Jesus was debriefing the seventy-two after their recent mission and had just turned to the Twelve for a private conversation when the lawyer interrupted. That shifts the framing to include consultation between Jewish religious teachers about Jewish law. Let us pause to define this crucial CL model, semantic framing.

A frame is a cluster of knowledge about real world experience (or cultural assumptions), which, once acquired, may be evoked in new situations and in linguistic interactions - in conversation, in reading, in telling or hearing a story. Frames have a Gestalt character; parts bring to mind or imply the whole. There is an inherent logic to a frame, and frames affect propositional structure. The goals and intentions in or of the frame affect our thinking when we use the frame. Communication within - and sometimes across - social-linguistic communities relies on shared frames. We use frames in everyday interaction, and we use them when we read. ${ }^{12}$

10 M. Turner, The Literary Mind: The Origins of Thought and Language (Oxford and New York: Oxford University Press, 1996), pp. 10, 26.

11 L. Ferrari and E. Sweetser, "Subjectivity and Upwards Projection in Mental Space Structure," in B. Dancygier and E. Sweetser (eds.), Viewpoint in Language: A Multimodal Perspective (Cambridge: Cambridge University Press, 2012), pp. 47-68.

12 G. Lakoff discusses the features of frames and their propositional structure in relation to idealized cognitive models in Women, Fire, and Dangerous Things: What Categories Reveal about the Mind (Chicago: University of Chicago Press, 1987), pp. 68-69. Charles Fillmore defines the term "frame" as follows: "I have in mind any system of concepts related in such a way that to understand any one of them you have to understand the whole structure in which it fits; when one of the things in such a structure is introduced into a text, or into a conversation, all of the others are automatically made available. I intend the word 'frame' as 
To enter Luke's reality as fully as possible, 21st century readers must have (or must acquire) certain frames. Culturally constructed worlds are frames; fictional worlds are frames. The Gospel according to Luke is a culturally constructed text relying on frames, and the parable embedded in our focal Lukan text evokes a (small) fictional world structured by frames. Expert readers and interpreters must attend to these cultural frames, but it is shared experiential frames that give modern readers our most immediate access to the world of the text.

\section{Experiential Frame: Conversation}

A key experiential frame that builds characterization in this pericope is that of ordinary conversation. Via that frame, readers (or hearers) can track the interaction between the main characters. Some specific features of a Conversation frame are displayed as the dialog opens in Luke 10:25. ${ }^{13}$

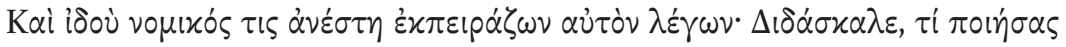

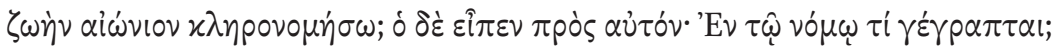
Kai idou nomikos tis anestē ekpeirazōn auton legōn Didaskale, ti poiēsas zōèn aiōnion klērovomèsō; ho de eipen pros auton. En tō nomō ti gegraptai; Just then a Torah scholar stood up to test Jesus. "Teacher," he said, "what must I do to inherit eternal life?" He said to him, "What is written in the Law?"

used here to be a general cover term for the set of concepts variously known, in the literature on natural language understanding, as 'schema', 'script', 'scenario', 'ideational scaffolding', 'cognitive model', or 'folk theory"' (C.J. Fillmore, "Frame Semantics," in Linguistics in the Morning Calm [Seoul: Hanshin, 1982], pp. 111-137). Fillmore introduced the notion of "the world of the text," and said, "the process of understanding a text involves retrieving or perceiving the frames evoked by the text's lexical content and assembling this kind of schematic knowledge (in some way which cannot be easily formalized) into some sort of 'envisionment' of the 'world' of the text." C. Fillmore, "Frame Semantics," p. 122. Regarding what readers must know or "pretend" to know in order to join the authorial audience, see P.J. Rabinowitz, Before Reading: Narrative Conventions and the Politics of Interpretation (Columbus: Ohio University Press, 1987), p. 96. Each frame is an idealized cognitive model (ICM) by which knowledge is organized and conventionalized, and each ICM structures a mental space, as defined by Fauconnier. Regarding ICM's and frames, see Lakoff, Women, Fire and Dangerous Things, p. 6.

13 Frame analysts customarily capitalize their names for frames. Here, Conversation is such a frame. 
The participants shift Speaker-Addressee roles and abide by the turn-taking conventions of a Conversation frame. ${ }^{14}$ A subframe, Question-and-Answer exchange, modifies it, as do culture-specific elements (the Lawyer stands, signaling respect for the Teacher). The question he poses may strike us as an odd one, coming from a Jewish lawyer. "Eternal life" was not a conventional Jewish theme, but it is part of Luke's vocabulary for salvation and may indicate the Torah scholar's awareness of a 1st century Jewish apocalyptic worldview and even adoption of those concerns, that frame. If so, that tells us something significant about him. The question can prompt readers to recall the narrator's expressed interest in the twin themes of salvation and the way of life Jesus taught in word and deed, a way of life lived in light of the new epoch zoèn aiōnion Jesus announces and inaugurates. ${ }^{15}$

Jesus' disciples are present to overhear the conversation; such silent witnesses can become another node in a conversation. This is display talk, in which what appears to be a dyadic conversation is actually (or also) carried out for the benefit of another (or group). When Luke says that the nomikos "wanted to justify himself," he allows readers' pictures of the framing event to include that larger group of silent witnesses. ${ }^{16}$

14 A basic frame for linguistic communication includes a shared language, an I and a You (Speaker \& Addressee) and turn-taking conventions. The first person and second person, I/you are linguistic universals, shared across human cultures. Eve Sweetser explains how ordinary conversation uses framing: "The Definition of Lie: An examination of the Folk Theories Underlying a Semantic Prototype," in D. Holland and N. Quinn (eds.), Cultural Models in Language and Thought (Cambridge: Cambridge University Press, 1987), pp. 43-66. "The same question recurs later in Luke 18:18, paralleled by Matt. 19:29 and Mark 10:17. The combination of terms does not occur in Torah. The 'inheritance' (klêronomia) promised the people is the land (Gen. 28:4; Deut. 1:8; 2:12; 4:1; cf. Acts 7:5) Ps. 15:5 [LXx] speaks of the Lord as one's inheritance, and Ps. 36:18 [LXx] of an eternal inheritance ..., but this is not connected to 'eternal life.' In Dan. 12:2 [LXx] on the other hand, the just will rise to 'eternal life.' In the NT, the idea of an 'eternal inheritance is found only in Heb. 9:15 although it is suggested by 1 Pet. 1:4. But the idea of 'eternal life' is frequently found (see e.g., Rom. 2:7; 5:21; 6:22-23; Gal. 6:8; Jude 21; and especially John 3:15-16, etc.). The other Synoptists use it only once but Luke has it in 18:18, 30; Acts 13:46, 48" (L.T. Johnson, The Gospel of Luke [Sacra Pagina; Collegeville: Liturgical Press, 1991), p. 175). Joel B. Green observes, "the content of the lawyer's question employs another of the range of terms Luke uses to depict salvation, "life" - in particular, "eternal life," a phrase that first appears in Dan. 12:2 and is then developed in apocalyptic Judaism to refer to the life of the coming epoch. The question itself is admissible and will provide the platform for Luke to expound on the behavior appropriate to an orientation to the resurrection" (J.B. Green, The Gospel of Luke, p. 428).

16 About "display talk," see Erving Goffman, Forms of Talk (Philadelphia: University of Pennsylvania Press, 1981). 


\section{The Basic Communicative Space Network and the Ground of Communication}

One way of thinking about the Ground is exemplified in the Basic Communicative Space Network model proposed by Sanders, Sanders and Sweetser. ${ }^{17}$ In this model, the act of communication is understood as necessarily evoking a core network of mental spaces, including:

A Content Space (the one in which characters and their actions exist, in this narrative) - this is in fact a network in itself, for a complex narrative.

A Speech-Act Space (the one in which the storyteller and his audience exist, in this case), in which the Content Space is embedded.

Epistemic Spaces which are attributed to the Speaker and the Addressee(s), in this case whatever beliefs and opinions we can manage to attribute to the storyteller and the questioner.

Base Spaces (for both S and A) of general background information, which is inherited by the specific situations in the Content Space, Speech-Act Space, etc. (In this case, we might for example assume that neither Jesus nor the lawyer nor any likely reader will question that inn-lodging normally needs to be paid for).

There are other spaces such as linguistic form-meaning mappings which Speaker and Addressee share. All of this is potentially embedded: "Luke's" narrative has Jesus' communicative act of story-telling embedded in it, and in that is embedded the communication between (for example) the Samaritan and the Innkeeper.

17 J. Sanders, T. Sanders, and E. Sweetser, "Responsible subjects and discourse causality. How mental spaces and perspective help identifying subjectivity in Dutch backward causal connectives, Journal of Pragmatics 44 (2012), pp. 191-213. And J. Sanders, T. Sanders, and E. Sweetser, "Causality, cognition and communication: A mental space analysis of subjectivity in causal connectives" in T. Sanders and E. Sweetser (eds.), Causal Categories Discourse and Cognition (Cognitive Linguistics Research, 44; Berlin and New York: De Gruyter, 20o9). 


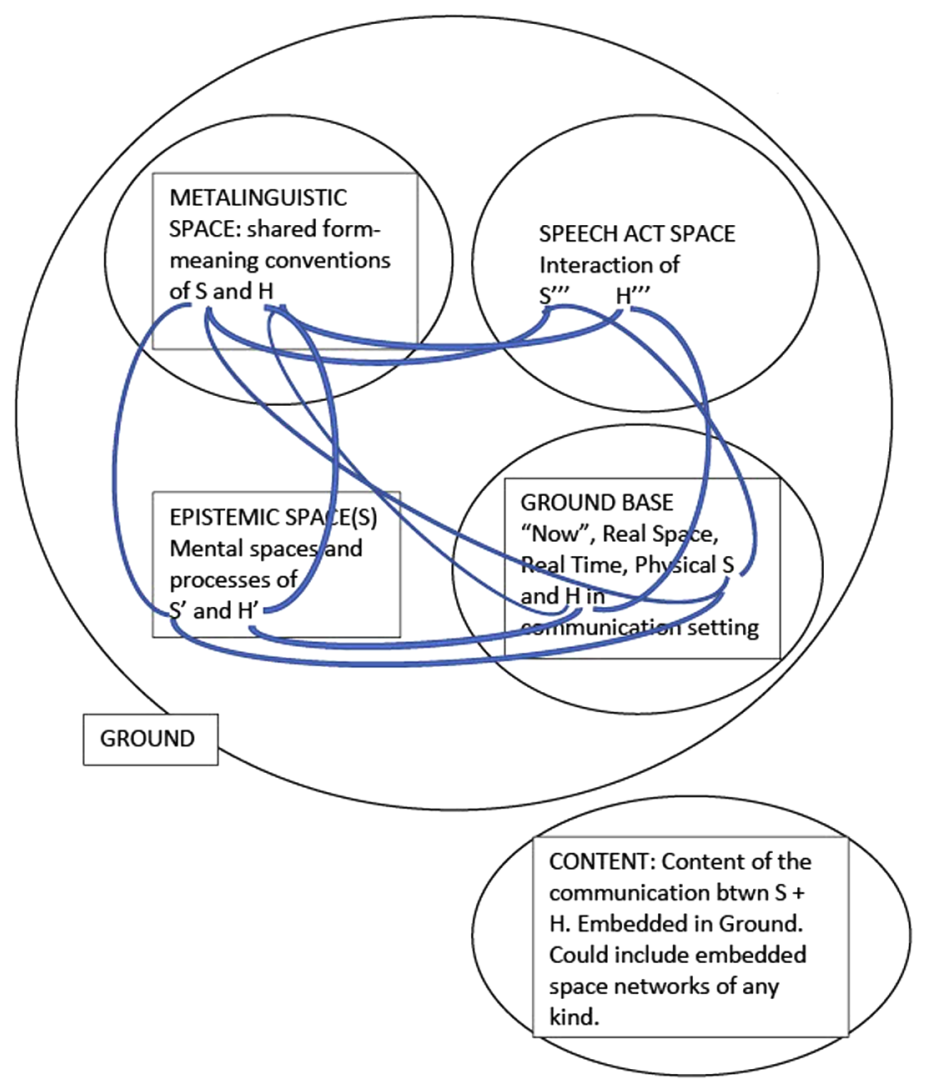

Basic Communicative Space Network

What this BCSN displays, basically, is that the mere statement that " $\mathrm{X}$ said Y" necessarily evokes all of these spaces, in connection with each other. The frame of Communicative Action automatically evokes this multi-space network as Ground.

Each of these Ground networks depends on assumptions of some shared cognitive structure between writer/speaker and reader/addressee. Therefore, at each level of a network, there is the possibility of sufficiently divergent mental space construction to be labeled misunderstanding. Needless to say, this possibility is particularly strong in the link between a reader and a writer who come from different cultures, historical periods and linguistic backgrounds. Will they share frames or not? Or perhaps more sensibly put, how similar will the frame evoked by a Koiné word be to the frame evoked by its most plausible English (or German, or Japanese) translation? Which aspects of the background knowledge inherited by the Base Spaces will actually be common to the two? 
Mental space construction is so automatic a process that it is very difficult for a reader to separate her understood elaboration of the content from the expressed content, even when frames are really shared. When we are (largely unconsciously) constructing and elaborating meaning based on frames quite different from those of a plausible author, reading is necessarily an open and dangerous process.

But what a BCSN structure lets us do is clarify for ourselves what frames we are constructing as part of what mental spaces in the network. For example, one instance of a BCSN is the reading frame of a modern reader of Luke's text. That reader is necessarily interested in how Luke's content helps him/her to judge Luke's mental states and intended communication to readers. Another BCSN (embedded in the CONTENT of the preceding one) is of course the conversation between Jesus and his questioner. Further BCSN structures embedded in the CONTENT of that second BCSN include the conversation between the Samaritan and the innkeeper. Do we know that we modern readers have access to the frames shaping the discourse of Jesus and his questioner? Do they/ do we know that the innkeeper and the Samaritan share frame structures (e.g. of journeying or compassion) with them? With us? The BCSN network reminds us to keep track of supposed similarities and differences between the mental spaces in the network.

This is the essence of understanding character in narrative. Without a constructed mental space for a given character - which is neither the mental space of the author or the reader, nor necessarily similar to mental spaces of other characters - we can't construct purposes or motives for the character's volitional actions.

Let us now consider some specific frames involved in this story, and how they contribute to the meaning.

\section{Framing and the Narrator's Power}

Our focal text is Luke's report of an interrupted conversation, and the narrator has tagged the interrupter "some lawyer" vopixós $\tau i \varsigma$ - nomikos tis. Though the portrayal of this particular Torah scholar includes some positive qualities, there's a scholarly consensus that Luke portrays "the scribes" ("lawyers," "teachers of the law") in mostly negative terms. ${ }^{18}$ Lawyers in Luke question and test Jesus' adherence to Torah teachings (cf. Luke 5:17, 21, 30; 6:7, 9, 22;15:2;

18 Johnson, The Gospel of Luke, p. 174. 
19:47; 20:19; 22:2, 66; 23:10). The narrator's negative appraisal of "the Pharisees and teachers of the law" who refused John's baptism and thus "rejected God's purpose for themselves" (Luke 7:30) becomes a narrative anchor informing and guiding expectations for the behavior and intentions of any member of that category, including our nomikos in chapter $10 .^{19}$ In addition to narrative anchoring and link-building, CL would name that kind of co-textual "access" frame evocation and networking. At the same time, any departure from the pattern with its negative expectations will stand out.

The Torah scholar calls Jesus $\Delta เ \delta \dot{\alpha} \sigma x \alpha \lambda \varepsilon$ - Didaskale vocative form of address < didaskalos, "teacher," which is the usual Koiné translation of Hebrew/ Aramaic rabbî, "my great one." ${ }^{20}$ What does this tell us about Jesus' character from this scholar's viewpoint? Roles like "Teacher" or "Rabbi" are metonymic for entire semantic frames; here the honorific stands for a particular respected social function, a category of social and religious status. Note that it is used not by a disciple, but an outsider. Some interpreters doubt the sincerity of the lawyer's deference; they hear an ironic or sardonic tone. But while on the face of it this Torah scholar addresses Jesus respectfully, he does not use "Lord," xúpı - Kyrie, as Peter has. (Luke 5:8)

The narrator also embeds some intention cues that modify the Conversation

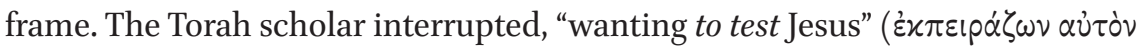
- ekpeirazōn auton). Ekpeirazōn signals hostile intent. ${ }^{21}$ Those words modify the Conversation frame, annexing an Honor Challenge subframe that carries spin (specific cultural expectations of challenge and riposte). The narrator signals that this lawyer has interrupted Jesus' private conversation with the Twelve, although that may not have been considered rude. ${ }^{22}$ It does matter who poses the first question, whose question comes last, and who has the last word; this is a polite conversation with agonistic overtones. Ordinary non-expert readers have an array of responses to this dialog, and their degree of familiarity with

19 On "narrative anchors" see Dancygier, Language of Stories, pp. 42-5o. Joel B. Green argues that "identification of this character as a 'lawyer' accesses earlier information provided by the narrator: (1) Legal experts have been present to monitor Jesus' faithfulness to the law. (2) Legal experts are among those identified as persons responsible for Jesus' pending rejection and suffering 5:17-19; 9:22" (J.B. Green, The Gospel of Luke, p. 427). CL explains such "access" via narrative (mental) space networks and links.

$20 \quad$ R. Riesner, "Teacher," DJG, pp. 934-939.

21 Johnson, The Gospel of Luke, p. 172.

22 Joel B. Green argues that Luke "pictures the lawyer breaking in on what had become a private conversation between Jesus and the seventy-two (v. 23). That the lawyer is present at all raises questions about the boundaries between the disciples and others outside of the circle of Jesus' followers both here and elsewhere in the journey narrative" (Green, The Gospel of Luke, p. 425). 
the first-century cultural frames will impact the readings they construe, and their constructions of imagined mental spaces and motives for characters.

\section{Cultural Frames: Lawyers and Neighbors}

When the Torah scholar asks what he must do to inherit eternal life, Jesus responds by asking him what the Torah (the Law) says, how he "reads" (interprets) it. The nomikos dutifully recites the summary of the Law from Deuteronomy 6:5 "Love the Lord your God with all your heart, soul, and strength, and," he adds, "with all your mind." Then he adds another Torah reference, from Leviticus 19:18

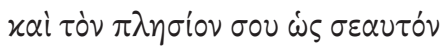

kai ton plèsion sou hōs seauton and [love] your neighbor as yourself

Jesus affirms that this is the right answer. But the lawyer has another question.

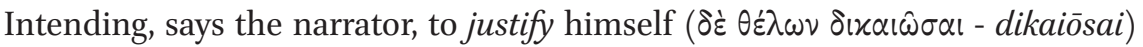
the nomikos asks Jesus: "And who is my neighbor?" Notice the injection of the narrator's viewpoint about the character's aims. That little phrase alters the purpose (a frame element) of this Conversation.

Now to the "Who is my neighbor?" question. Clearly, even very general biblical laws apply in different ways to different relational categories of people. As with so many rabbinical disputes, this legal interpretation hangs on the defining frame - in this case, of Neighbor. And this will be the subject of Jesus' parable. The Greek word $\pi \lambda \eta \sigma i o v$ - plēsion "near" - certainly did apply literally to someone living in the immediate physical vicinity. But of course, the meaning is not in the word, all by itself. The literal spatial-orientation frame evoked by "near" becomes (via frame metonymy) a social-relational one, and it is a reciprocal relationship. ${ }^{23}$ If you live near to someone, they live near to you, so you

23 "A person who lives close beside others and who thus by implication is a part of a so-called 'in-group,' that is, the group with which an individual identifies both ethnically and culturally - 'neighbor, brother." Louw and Nida further observe that of the three terms, $\gamma \varepsilon i \tau \omega \nu$,

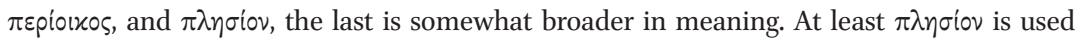
in Luke 10.27 in a somewhat extended sense of 'fellow man,' .... The translation of $\pi \lambda \eta \sigma i o v$ as a singular in Luke 10.27 may pose a problem in understanding, since the singular may be understood in a specific rather than in a generic sense, that is to say, 'love your neighbor as yourself' might immediately give rise to the question 'which neighbor?' therefore, one must often translate Luke 10.27 as 'you must love your neighbors as you love yourselves' or 'you must love other people as you love yourselves"' (Johannes P. Louw and E. Nida [eds.], 
are your neighbors' neighbor. "Neighbor" assumes or creates social relationship; the word brings up added non-geographic frames of social relationship as well as of norms of reciprocal neighborly treatment. ${ }^{24}$

But what is the question, really? Surely the scholar knows his next-door neighbors. Perhaps the Lukan narrator is presenting him as wanting to know, "OK, does 'neighbor' mean everyone in my town? Everyone in my tribe? Every Jew?" Or "How much neighborly assistance is entailed?" How "far" does Love thy neighbor go? This is a framing issue, then. But Jesus will do much more than merely offer a definition of the scope of that category.

The specific relevant frame elements for Neighbor in this cultural context are debated. Here is where the CL model requires as much socio-cultural information as can be gathered about the particular frame. Would everyday "neighborliness" have entailed taking on a neighbor's financial obligations on top of emergency assistance? Would it have applied to a stranger who happened to be traveling the same road with you, far from both your homes? Certain от passages will be of assistance in the work of frame element construction (e.g., Exod. 11:1-2; Lev. 19:8, 34 and Deut.10:18), and scholars want to consider the range of 1st century Jewish understandings of obligations towards Gentiles, non-Jews, and Samaritans. ${ }^{25}$

The Torah scholar's questions and answers in this opening dialog are true to type. That is, he is a paragon of the category, the lawyer-characters in Luke's Gospel. He knows his Torah, displays genuine curiosity about this new teacher, Jesus, and yet he seems somewhat skeptical and defensive. He can recite the heart of the Torah, but he does not yet see how the Jewish religious establishment fails to live Torah, from the viewpoint that Jesus is going to show him with

Greek-English Lexicon of the New Testament Based on Semantic Domains, 2nd edn, 11.89 [New York: United Bible Societies, 1988, 1989], 1:135).

24 "In its co-text in Leviticus, love of neighbor is a disposition of the heart expressed in tangible behaviors - related, for example, to a neighbor's honor and possessions. Jesus concurs with the lawyer's answer, and rightly so, given the impressive degree to which it meshes with Jesus' own message. Indeed, the lawyer has stated more succinctly than Luke has recorded of Jesus the need for a comprehensive love of God, encompassing uncompromising allegiance and conformity to his purpose, from which springs love for others. Of course, it is one thing to interpret the law correctly, another to internalize and perform it" (J.B. Green, The Gospel of Luke, p. 428).

25 L.T. Johnson notes that Lev. 19:18 "makes 'sons of your own people' (i.e., fellow-Israelites) as equivalent to 'neighbor.' Later, in Lev. 19:33-34, this is extended to the ger ('stranger' or 'sojourner') in the land. Since the LXx translated this as prosēlytos ("proselyte"), the attitude of love was still rather restricted. Among sectarians like those at Qumran, the division between love for the sons of light and hate for all others was absolute. (cf. 1QS 1:9-10) For the Pharisees, discussion of the limits of interaction with non-Jews was extensive, as e.g., $m$. Abodah Zarah 1:1; 2:1-2; 4:9-10)" (Johnson, The Gospel of Luke, pp. 172-173). 
the parable. Luke, then, presents this lawyer as needing to hear Jesus explain to him what he's missing - why he has not yet entered into the everlasting life

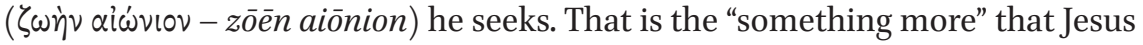
is offering and embodying. Thus, Luke's evangelistic and apologetic agenda shapes (frames) the pericope, including the parable, to which we now turn.

\section{Characters in the Parable - Dramatis Personae}

Let us review the cast of characters in Jesus' parable. A Human Being -

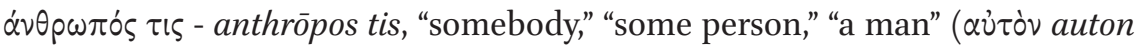
"he, him") This cursory designation forces readers to fill in the profile of this character. He is male, probably Jewish. ${ }^{26} \mathrm{He}$ is stripped, erasing those marks of identity and status (cf. Luke 15:22; 16:19-20; Acts 12:21). Readers can infer that he is exposed and humiliated, adding emotional trauma to the physical beating that leaves him near death. But readers can also bank on knowledge built up from observing Lukan anthrōpoi to this point, and perhaps their knowledge of what is yet to come in Luke-Acts. In a sense, this victim could be nearly anyone. The flatness of the character allows it to map onto any human being, a powerful entailment of the framing.

The bandits (assailants) - We are not told how many bandits there are, but the narrative framing implies that they were Jewish men. If it were otherwise, the storyteller would have said so. Their actions, but not their motives, are described: they stripped the man, beat him, and went away, leaving him halfdead. Why? The storyteller doesn't say. His purpose in telling this tale lies elsewhere. It is not about examining the motives behind the assault or dwelling on the specifics of those who commit the assault; this is another gap that readers must fill in. The assailants' actions create the focal problem of the drama, but they leave the scene immediately and the spotlight will be focused on others' actions.

The priest and the Levite - Their roles are given, but not personal names, allowing them to stand (via category metonymy) for the categories of people to which they belong. They do not say anything, and neither the storyteller nor the main narrator indicates anything about motives or intentions driving their behavior. That leaves room for interpretation, which is why scholars debate which elements from cultural frames are evoked: whether corpse impurity or

26 An assault on a woman would present a very different picture and have vastly different implications in that culture, just as it does in the modern era. 
other purity customs are in play; whether the inherited status these figures enjoy frees them to walk on by with moral impunity. ${ }^{27}$

The innkeeper - He is another stock, two-dimensional figure with a non-speaking part. Instructions are given to him, but readers must fill in the gaps, imagine what the innkeeper does or might have said. ${ }^{28}$ The CL point is that this gap-filling is required - enabled by mental space networks and frame Gestalts.

Most of the parable characters, then, are two-dimensional, as is common with the parable genre. Parables operate with stock characters and conventional actions; that is how they become so portable, so widely projected and applied. $^{29}$

The Samaritan, by contrast, stands out. Jesus describes in some detail what he does, so that hearers can see him pour oil and wine on the wounds, lift the man, and carry him on his pack animal to an inn. In fact, the full range of human sensory perception is available; the story may evoke sounds, smells, haptic memories, and more. This is embodied cognition in the reader. Jesus also reveals the Samaritan's intentions, and indicates something about what spurs him into action.

\section{Experiential Frames Structuring the Parable: Travel, Needy Person Challenge}

The parable is shaped by a Journey frame with standard Frame Elements: A traveler; a path; a starting point; a destination; a purpose. This story has those core frame elements with added variations. The road is named: it is the one running between Jerusalem and Jericho. This road is known to be dangerous,

27 Regarding conjectures about corpse impurity, e.g., K.E. Bailey, Through Peasant Eyes (Grand Rapids: Eerdmans, 1980), pp. 44-46. But here the Temple functionaries are travelling away from Jerusalem and, as J.B. Green points out, "even priests had an obligation to bury a neglected corpse" (Green, The Gospel of Luke, p. 430). And see C.W. Hedrick, Parables as Poetic Fictions: The Creative Voice of Jesus (Peabody: Hendrickson, 1994), pp. 106, 115.

28 Ruben Zimmermann has suggested that the innkeeper and the Samaritan are both unexpected heroes due to the many prejudices against them in Jewish and Greek literature. Luke favors unusual heroes elsewhere as well (Luke 15:9; 15:20; 16:1-8; 18:1-8; 18:9-14). R. Zimmermann, "Berührende Liebe" (Der barmherzige Samariter) - Lk 10,30-35, in R. Zimmermann (ed.), Kompendium der Gleichnisse Jesu, (Gütersloh: Gütersloher Verlagshaus, 2007), pp. $53^{8-555}$.

29 Regarding conceptual blending in parables, and parables as source tales projected onto many targets, see M. Turner, The Literary Mind: The Origins of Thought and Language (New York and Oxford: Oxford University Press, 1999) pp. 5-11. 
and the story includes an Assault account with a Rescue subframe. The direction of travel is disclosed: Down to Jericho, rather than up to Jerusalem. The origin and the direction of travel are "loaded" for social-cultural contextual reasons. ${ }^{30}$

Thus, the Jericho Road becomes the setting for observing the behavior of our small cast of characters. Readers/hearers see each display his character as we are told what he does, or what is done to or for him when he goes down this road. In CL terms, the parable displays multiple distinct viewpoint affordances on the same scene. ${ }^{31}$ The first traveler, "some man," is assaulted by bandits who leave him for dead by the side of the road. Next, in sequence, the priest and a Levite appear. Both see the assault victim and pass him by on the other side. Finally, the fourth traveler, a Samaritan, approaches and interacts with the wounded man.

Notice the syncopated action and the rhythmic parallelism in the Greek text's phraseology:

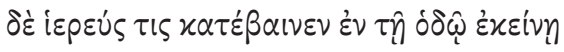

de hiereus tis katebainen en tē hodō ekeinē

now a priest was going down [in] that same road]

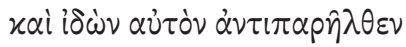

kai idōn auton antiparēlthen

and seeing him [he] passed by on the other side

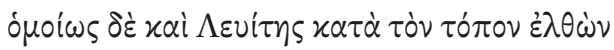

homoiōs de kai Leuitēs kata ton topon elthōn

in the same way - [a] Levite having come to the place

xai i $\delta \dot{\omega} \nu \dot{\alpha} \nu \tau \iota \pi \alpha \rho \hat{\eta} \lambda \theta \varepsilon v$

kai idōn antiparēlthen

and seeing [he] passed by on the other side

30 Josephus, J.W. 2.12.2 §§228-3ol; Strabo, Geogr. 16.2.41; Bailey, Through Peasant Eyes, pp. 41-42.

31 Viewpoint is a communicative and linguistic constant, structured by mental spaces. Viewpoint in narrative is built on viewpoint in everyday communication but has distinctive features. As we read and interpret any text, readers encounter language expressing what imagined characters can touch, see, say, hear, (anticipate? presuppose or assume?), and feel. Humans never have direct access to what another thinks or feels, so we are always relying on our imagined projections and estimations. B. Dancygier and E. Sweetser (eds.), Viewpoint in Language: A Multimodal Perspective (Cambridge: Cambridge University Press), pp. 47-68. 
Attentive readers mentally simulate that repeated action, and Koiné readers hear the conceptual linkage in the verb forms: kai idōn antiparèlthen. But when the Samaritan comes down the same road:

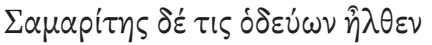 \\ Samaritēe de tis hodeuōn èlthen \\ But a Samaritan came travelling

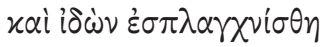 \\ kai idōn esplanchnisthē \\ and seeing was moved with compassion
}

The Samaritan breaks the established rhythm when he does not pass by on the other side. Instead, he is moved with compassion, pity: esplanchnisthe $<$ splanchnizomai - aor. passive; being moved to pity in one's inward parts - gut $(\sigma \pi \lambda \alpha \gamma \chi \nu \alpha /$ splanchna $)$.

Here is the pivotal moment - and embodied concept - of the parable and the pericope. It is this gut-level feeling that moves the Samaritan to respond, to move towards the victim rather than away from him. ${ }^{32}$ His inward response causes him to act: to draw closer, treat the wounds, lift the man onto his beast of burden, transport him to a shelter, stay with him overnight. When morning comes, he pays the innkeeper, asks him to provide care, and promises to return and pay additional expenses. The Samaritan gets more ink than the priest and Levite do because the Samaritan does more. But he does what he does because "when he saw, he felt compassion." The Samaritan displays the same emotion that Jesus has displayed (Luke 7:13) - linking the two (via conceptual blending) in this key character trait. ${ }^{33}$

The crucial cultural frame is the ist century understanding of the gut as the locus of emotional response and empathic energy (not the heart, as in modern framing). ${ }^{34}$ In a shocking move for Luke's first readers, the Samaritan touches

32 Menken showed that splanchna and splanchnizomai signal the turning point of each Lukan pericope in which they occur. M.J.J. Menken, "The Position of Splanchnizomai and Splanchna in the Gospel of Luke," NT 30 (1988), pp. 107-114.

33 L.T. Johnson notices that connection and writes, "The Samaritan's involvement began with his choice to 'approach' rather than pass on the other side. Then he felt compassion, and came even closer" (Johnson, The Gospel of Luke, p. 173). Also, the bodily response of the Samaritan could trigger a memory in the reader of their own normal human bodily response to a sight of terrible suffering.

34 D.J. Williams, "Mercy," DJG, pp. 542-543. 
the man left for dead. He stays with him. He pays for his care and promises to return and to pay even more. All of the Samaritan's behavior clashes with conventional cultural expectations for his category of person. From a conventional 1st century Jewish point of view, he is a social and religious "other."35 Jesus plays with that set of expectations when his Samaritan fulfills the spirit of the Torah better than the officially religious Jewish figures - the priest and the Levite. The Samaritan becomes the paragon, going above and beyond the traditional call of duty when he provides long-term shelter, food, and care. He speaks a few words near the end of the story, giving instructions for the innkeeper. But the Samaritan's actions display his character more convincingly than anything he says.

Actions speak louder than words, in this parable. The victim, the bandits, the priest, the Levite, and the innkeeper - none of these characters speaks. Neither the main narrator nor the storyteller offers direct access to the mental states of any of the characters in the parable, only what they did - except for the Samaritan. We are not told why the lawyer and the priest don't decide to help the man lying beside the road. Readers have to construct who they are by watching what they do. But this silence gives readers license to fill in the gaps, to project, to imagine - and pushes them to focus on the Samaritan's compassionate response.

The physiological experience of compassion the Samaritan allows himself to feel is the driving force behind his behavior. ${ }^{36}$ Attention to that human psycho-physiological reality is an important cue for the reader/hearer; it is a point of bodily experience that the reader knows, and it can evoke deep resonance, embodied understanding of the parable. It draws attention to the priest and Levite's behavior as well, as it evokes discomfort and tension, giving rise to the question, Why are they passing him by? Thus, we have a vast NT scholarly debate about what religious customs or rules might be guiding their behavior.

\section{Back to the Dialog - And What must I Do?}

Attentive readers of Luke observe at least two viewpoints on the parable's characters - via the post-parable dialog between Jesus and the Torah scholar. The

35 A.D. Crown (ed.), The Samaritans (Tübingen: J.C.B. Mohr [Paul Siebeck], 1989); H.G.M. Williamson, "Samaritans," DJG, pp. 725-27.

36 Modern neuroscience corroborates the physical basis of empathy in the presence of pain. Preston, Stephanie D., Bechara, Antoine, Damasio, Hanna, Grabowski, Thomas J., Stansfield, R. Brent, Mehta, Sonya and Damasio, Antonio R., "The Neural Substrates of Cognitive Empathy," in Social Neuroscience (online publication date January 2007) pp. 254-275. https:// 
storyteller (Speaker) checks in with his primary Hearer (Addressee), asking in Teacher mode (Didactic Dialog framing):

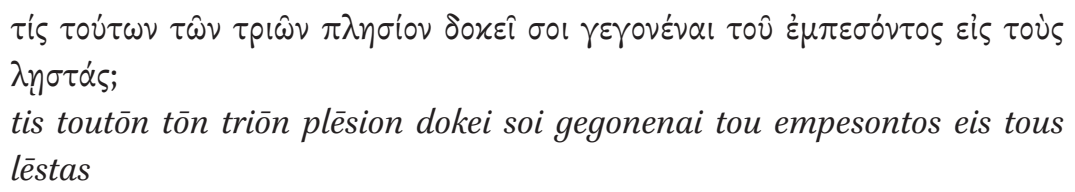

Which of the three do you think turned out to be a neighbor to the one who fell among bandits? ${ }^{37}$

The Torah scholar's opening question had been, "What must I do to inherit everlasting life?" Now the Questioner/Answerer roles switch: Jesus poses the closing question; the Torah scholar must answer. But the two have retained their basic roles in the Didactic Dialog frame: Jesus is always the Teacher. Notice his respectful, non-agonistic Socratic teaching method: This teacher asks an open, generous question and affirms the student when he gives the correct answer:

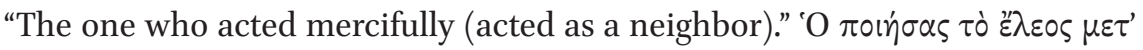

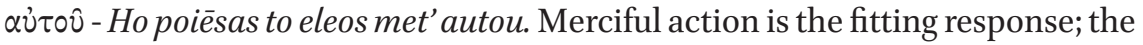
Torah scholar shows he has understood Jesus' parable, and displays an unforeseeable development in his character. ${ }^{38}$

Jesus - still filling the Torah Teacher role and demonstrating extraordinary pedagogical skill and sensitivity - returns to the opening question. His imperative Go $D O$ this! refers to the lawyer's original question about the way to inherit eternal life. The parable is in essence Jesus' response in story form to the lawyer's first question. Joel Green argues that it is a kind of narrative exegesis. ${ }^{39}$

Questions and answers have framed the pericope. But the frame has not been inert, static. How have the questions and answers changed in the course of the conversation and in light of the parable? How does this narrated episode of disputation on a point of Law diverge from conventional framing to reveal Gospel in Luke? Luke T. Johnson finds the parable itself shocking, but observes:

doi.org/10.1080/17470910701376902 For a summary of what is at stake when these physical human responses become "invasive" for viewpoint, see Eve Sweetser, "Creativity Across Modalities in Viewpoint Construction," in Language and the Creative Mind, edited by Mike Borkent, Barbara Dancygier, and Jennifer Hinnell (CSLI Publications, 2013), pp. 239-254.

37 Here we adopt Luke Timothy Johnson's apt translation. L.T. Johnson, The Gospel of Luke, p. 171.

38 J. Rüggemeier, "Strategisches Erzählen und Strategiewechsel im Umfeld neutestamentlicher Erzähltexte. Daslukanische Gleichnis 'Vombarmherzigen Samariter' als Anschauungsbeispiel," DIEGEIS - Interdisciplinary E-Journal for Narrative Research 5.2 (2016), pp. 63-83. 
More stunning still is the use to which Jesus turns the parable. The point, we learn, is not who deserves to be cared for, but rather the demand to become a person who treats everyone encountered - however frightening, alien, naked or defenseless - with compassion: "you go and do the same." Jesus does not clarify a point of law, but transmutes law to gospel. One must take the same risks with one's life and possessions that the Samaritan did!40

Luke has been showing readers Jesus transmuting Law to Gospel without denigrating Torah. Here in chapter 1o, there is not even a hint at supplanting Torah. Though temple personnel fail to shine in the parable, Torah itself enlivens and guides the compassionate action that demonstrates the way to live, the way into zōen aiōnion. That vision is what makes this pericope more than a moral lesson or a nice story about care for the needy.

\section{Reading \& Interpretation Process: Narrative Uptake and Transport}

Storytelling arises from our basic human "need to share information and to arrive at social, and also linguistic, norms in the process." ${ }^{31}$ Change or revision of communal norms involves critique and adoption of alternative points of view. ${ }^{42}$ That is exactly what characterization offers readers a chance to explore in this pericope. The parable itself can evoke compassion and empathy or dislike, disgust and revulsion - or both sets of responses. Dancygier calls the processes by which stories evoke physiological responses like compassion, fear, or outrage "narrative up-take" and "narrative transport."43 She borrows these terms from cognitive psychologist Richard J. Gerrig, who said "readers are often described as being transported by a narrative by virtue of performing that narrative." 44 Readers become travelers, says Gerrig, and "the traveler assumes

40 Johnson, The Gospel of Luke, p. 175.

41 Dancygier, The Language of Stories, p. 17, quoting Tomasello. See M. Tomasello, The Cultural Origins of Human Cognition (Cambridge: Cambridge University Press, 1999).

42 Mark Turner writes, "We imagine realities and construct meanings. The everyday mind performs these feats by means of mental processes that are literary and that have always been judged to be literary. Cultural meanings peculiar to a society often fail to migrate intact across anthropological or historical boundaries, but the basic mental processes that make these meanings possible are universal. Parable is one of them" (M. Turner, The Literary Mind, p. 10).

43 Dancygier, The Language of Stories, p. 18. R.J. Gerrig coined those terms in Experiencing Narrative Worlds, New Haven: Yale University Press, 1993. https://sites.ualberta.ca/ dmiall/ LiteraryReading/Readings/ Gerrig\%2oExperiencing\%2o Narrative.pdf

44 Gerrig, Experiencing Narrative Worlds, 2. Gerrig refers to the experience modern readers have of "getting lost" in a book or feeling somewhat disoriented when we emerge from a movie. 
certain new characteristics (as called for by the narrative) as a consequence of undertaking the journey."45 Readers leave some aspects of their own worlds behind in order to enter into the story world; and when that happens, "The traveler returns to the world of origin, somewhat changed by the journey."46

Consider this: Does the Torah scholar allow himself to take such a journey? Has he been changed by his journey with Jesus into this parable world, so that his reading of the Torah's command to love the neighbor is revised? When he recognizes eleos - mercy - in the Samaritan's actions, it sounds like his circle of neighborly caring and moral responsibility has been expanded beyond tribal reciprocity and ethnic loyalty. That would be radically reframing Neighbor. Even more radically, has the nomikos gained a new understanding of what it means to "inherit eternal life"? People who are inheriting eternal life will naturally live the Samaritan's way - responding mercifully to anyone in need. They will not need to parse the definition of "neighbor" at all. ${ }^{47}$ Does the Torah scholar then model for readers how traveling in this parable world can transform them? The CL claim is that human embodied cognition primes, enables, and even requires that readers take such journeys.

\section{Decontextualization, Recontextualization and Transposition}

A key component of actively imagining the parable's scenario and travelling in its world is character construction. Readers who cannot see and hear the Samaritan's actions, or feel the silence of priest and Levite and watch them walk away, will not understand the parable. If a reader cannot identify with any of the characters, the reading will fail. And yet there are options. There is no one "correct" reading. Amy-Jill Levine notes that the parable offers "the possibility of interpreter identification with the wounded man rather than [with] the Samaritan who gives aid. The standard reading is the one in which 'we' are the Samaritans; 'we Samaritans' help 'them,' the sick, the poor, foreign nationals, and so on."48 There are also non-standard (and substandard) readings. Levine complains elsewhere: "The parable of the Good Samaritan has come

Some modern novels include characters who tell stories to other characters - as happens in our pericope. Gerrig remarks that at that point, readers "are actually several cognitive layers deep" (Ibid., p. 8).

45 Ibid., p. 11.

46 Ibid., p. 16.

47 On the re-framing of the "neighbor" question, see Green, The Gospel of Luke, p. 426.

48 A.-J. Levine, Short Stories by Jesus: The Enigmatic Parables of a Controversial Rabbi (New York: Harper-Collins, 2014), p. 79 . 
to mean whatever we want it to mean." ${ }^{39}$ Her frustration with farfetched or implausible readings that fail to attend to the cultural context of the parable is valid, but Levine has overstated the case. While the parable has a wide range of interpretations, frame analysis implies that it cannot be made to mean whatever readers want it to mean.

Decontextualization does affect readings and interpretations of this parable and its construal of its characters. A CL perspective on the problem begins with the observation that in a sense, once the utterance (or text, in this case) is encountered by anyone other than the author, there's a level of decontextualization. Beyond that, though, by now this text has become a cultural artifact, often divorced from its Lukan and canonical context. ${ }^{50}$

There are three related losses in decontextualization. First, there is loss of the framing event, the Lukan co-textual story. Many - maybe now a majority - of people in the increasingly secularized, biblically illiterate USA who see "Good Samaritan Hospital" on a building do not know the story that it comes from at all. Without the story, people connect the words to whatever frames are evoked for them. Or they let the name of the hospital remain mysterious for them. The mind makes meanings and - as Amy-jill Levine lamented, those may have little or nothing to do with what Luke (or Jesus) meant. In that sense, the text can come to "mean" whatever we want it to mean.

At the same time, decontextualization causes loss of the 1st century socio-cultural frame elements - and the frame Gestalts. Modern readers face extreme decontextualization because even New Testament scholars are not speakers of Koiné and do not belong to that language community, with its cultural and semantic frames.

Thirdly, there is often loss of the intertextual network to which the story belongs or belonged. Some Scripture study groups will be aware of the Markan parallel text (Mark 12:28-34) that includes discussion of the Shema and the neighbor-love command. Those same reading circles - as well as the community of expert scholarly readers - will bring to the reading what they know about Samaritans, priests and Temple personnel, inns and innkeeping, and as well as related Hebrew Bible passages, characters, and themes. That is the (deliberate) work of re-contextualization. Recontextualization can happen via restoration or retrieval of the story and its narrative framing, acquisition of

49 Ibid., p. 8o.

$5^{\circ}$ "Once the text becomes a shared cultural artifact, it participates in the system of distributed cognition and is no longer treated as one speaker's communicative contribution" (B. Dancygier, The Language of Stories, p. 18). 
the relevant cultural frame elements and reconnection with the intertextual networks.

Yet another stage or phase is the kind of recontextualization that moves into transposition. Preachers attempt this all the time, when they transpose NT narratives into the key of 21st- century framing in a particular location. Translations and paraphrases do that kind of transposing, as well.

Consider, for example, the way Clarence Jordan treated Luke 10:25-37. Jordan was a New Testament Greek scholar, a preacher, and a white civil rights activist in Georgia. In his 1969 Cotton Patch Version of Luke and Acts, Jordan casts the lawyer who confronts Jesus in Luke as a Sunday School teacher:

One day a teacher of an adult Bible class got up and tested him with this question: "Doctor, what does one do to be saved?" Jesus replied, "What does the Bible say? How do you interpret it? ${ }^{51}$

Notice how Jordan changes the lawyer's question. He has transposed the original question about how to inherit eternal life (zoên aiōnion) into American Southern evangelical idiom: "to be saved." Then in his parable paraphrase, Jordan maps the Jericho Road onto the highway (now I-85) between Atlanta (the capitol city) and Albany, Georgia. The robbers become "gangsters" who, "When they had robbed him of his wallet and brand new suit, they beat him up and drove off in his car, leaving him unconscious on the shoulder of the highway." 52 The priest and Levite become a white preacher and a Gospel song leader who, when they saw the victim, "stepped on the gas and went shooting by." The Samaritan? He is a Black man who stops and helps the white victim, lifts him into the back seat of his car and takes him to a hospital in Albany.

What Jordan does is pick out certain elements of the 1st century cultural frames - Samaritans, priests, Levites, wayside inns - and map them onto his contemporary cultural setting. This is mental space blending, and we can use a diagram to display how it works.

\footnotetext{
$5^{1} \quad$ C. Jordan, The Cotton Patch Version of Luke and Acts (Piscataway: Association Press and New Century, 1969), p. 46.

$5^{2} \quad$ Ibid.
} 


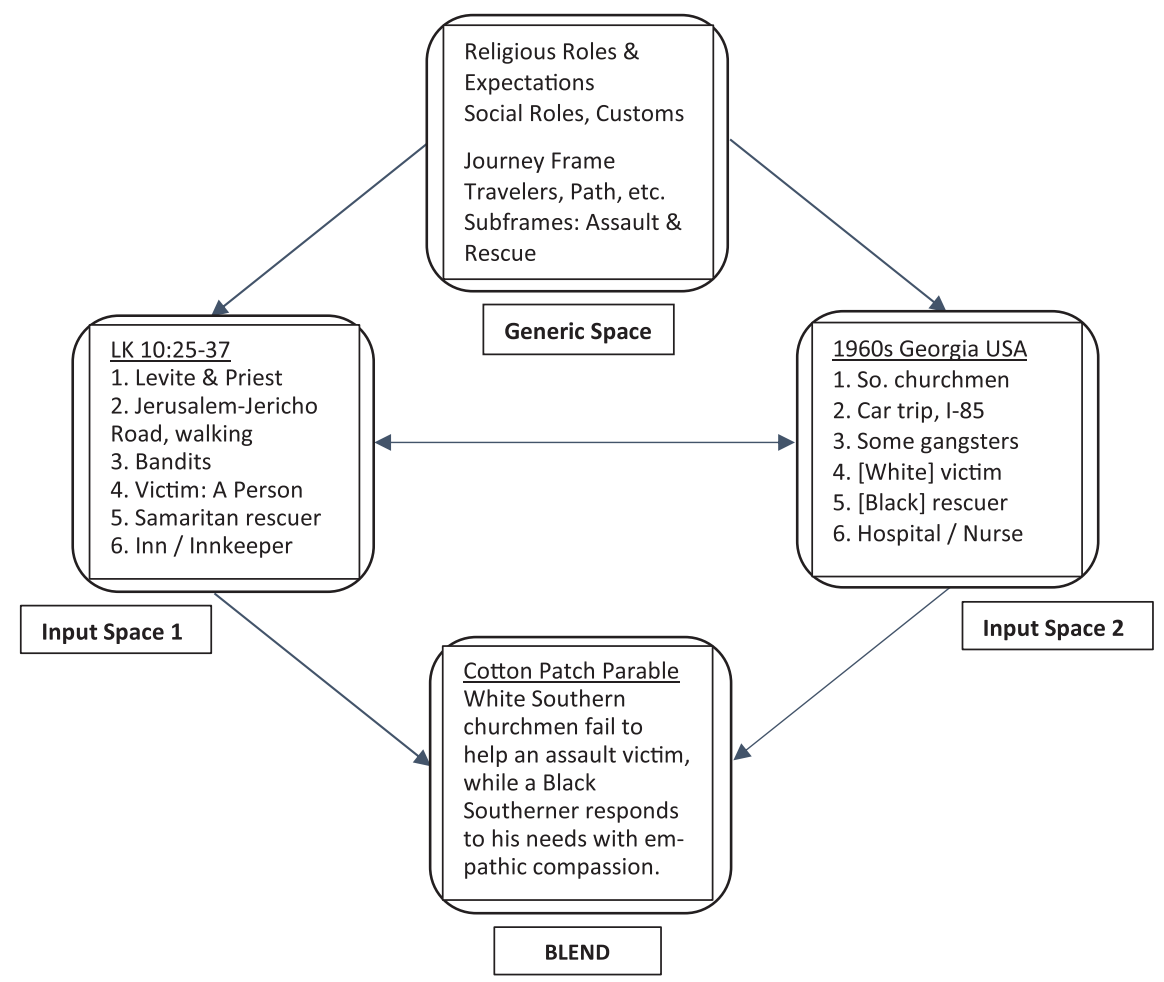

Blend: C. Jordan Reading

Running the Blend: Jordan has mapped what he reads in Luke (his interpretation of the text) onto his cultural context in 196os Georgia. Class assumptions and role expectations for a good preacher or Gospel song leader shape the characters who "stepped on the gas." (Always be on time; don't get involved with weird people). But the Black man knows how it feels to be beaten and abandoned, so he stops and helps. While in Luke the Samaritan transported the Jericho Road victim on his pack animal and took him to an inn, here the Black man puts the victim in his car and drives him to a hospital in Albany. It is compassionate response that links the rescuers in both scenarios. Jordan includes a footnote in which he imagines what the white preacher was thinking:

His homiletical mind probably made the following outline: 1 . I do not know the man. 2. I do not wish to get involved in any court proceedings. 3. I don't want to get blood on my new upholstering. 4. The man's lack of proper clothing would embarrass me upon my arrival in 
town. 5. And finally, brethren, a minister must never be late for worship services. ${ }^{53}$

Then Jordan imagines the Black man's thinking:

All the while his thoughts may have been along this line: "Somebody's robbed you; yeah, I know about that, I been robbed, too. And they done beat you up bad; I know, I been beat up, too. And everybody just go right on by and leave you laying here hurting. Yeah, I know. They pass me by, too." 54

Jordan's notes expose his (transposed) characters' intentions to a degree that the source text does not. He is elaborating, spinning out a 196o's Southern Gospel riff on the original frames. The genius of Jordan's Cotton Patch Version, though, lies in the way his casting of the hero as a Black man had the potential to shock and offend his readers in just the way that Jesus' Samaritan would have bothered his hearers and, by extension, also angered Luke's first readers.

What licenses that kind of recontextualization, in CL terms? The cognitive linguist and scientist Benjamin Bergen said this:

If meaning is based on experience with the world - the specific actions and percepts an individual has had - then it may vary from individual to individual and from culture to culture. And meaning will also be deeply personal ... the processes of meaning are dynamic and constructive. It's not about activating the right symbol, it's about dynamically constructing the right mental experience of the scene. ${ }^{55}$

Reading and interpreting are dynamic processes. The Lukan frames came with an elaborate, culturally-embedded scenario which the spare words of the told parable had potential to activate for 1st century readers, Luke's first readers. The expert modern reader, Jordan, then mapped some of the unspoken (Gestalt) content (entailments) of the text's frames onto his more elaborated modern target scenario. Thus, the modern interpreter's understanding of his contemporary context is allowed to strongly color or flavor the interpretive Blend. One could argue that Jordan's paraphrase evokes the right mental experience of the scene better than a straight translation would in his cultural context

53 Ibid., p. 47 , n. 7 .

54 Ibid., n. 9 .

55 Bergen, Louder than Words, p. 16. 
in the 196o's US South. But the Cotton Patch Version would not be expected to fit other contexts. There is no "one-size-(or culture)-fits-all" translation or interpretation.

This is why translators vary so widely in their construal of what is a "good" or "accurate" translation. A translator may hope, for example, to prompt readers to build mental spaces which resemble as closely as possible those intended (as far as the translator can reconstruct!) by the original writer - at least ones which could plausibly be attributed to a writer of that time and place. For example, a Shakespeare translator could be trying to transport modern Polish or Arabic language readers or playgoers into the Shakespearean worldview so that they can experience the plays as the original audience did. Or a translator may hope to prompt readers to construct a cognitive experience parallel in some way to the (plausibly reconstructed!) experience of readers in that time and place. The Shakespeare translator, then, could recognize that Shakespeare's contemporary audience did not have to embrace a foreign, archaic worldview to appreciate the work - so the translator could try to give us something that does for a 21st century audience what the Shakespeare text did for its original audience. This second strategy is taken by modern Bible translations such as The Message, or The Cotton Patch Version.

The CL point is that such "construal" is required; readers do not have immediate "clean" access to how Luke and his audience were thinking and are necessarily constructing Luke's and his first audience's mental spaces.

\section{Constraints and the Range of Meaning}

Are we back to Levine's complaint: The Good Samaritan means whatever we want it to mean?

CL says no. There are constraints on the plausible range of readings. The aptness, the fit, of mappings from the Source text to a Target translation, paraphrase, or interpretation can be evaluated - but not dictated. The links interpreters propose can be analyzed. It is a matter of degree of fit. But what else? Limits reside in the Lukan text in front of the reader, whose job it is to let its frames and constructions be activated. The trouble with translation - the "misery and the splendor" of translation - is that frames in the source text and target language are going be different. ${ }^{56}$ Good translation attempts to evoke meanings that are compatible, as close to "the same" as possible.

56 Referring to the 1937 study of translation by J. Ortega y Gasset, The Misery and Splendour of Translation; see the essay by P. Ordóñez-López, "The Misery and Splendour of Translation: A Classic in Translation Studies," in Computer Science 2009. 
There is one basic limiting factor in the variability of all readings. Cognitive Linguistics does assume that there are shared conventions of mappings between form and meaning. Within a linguistic community, even people with serious disagreements about values must still use the shared language and be aware of others' access to the same shared meanings. A speaker cannot, like Humpty-Dumpty, declare that a word means what he or she wants it to mean. This is equally true of grammatical constructions, which are also shared conventions of form-meaning mappings. A plausible reading necessarily has to be one which results from putting together conventional (frame-based) meanings in conventional grammatical patterns. Within that limitation, readers are free to elaborate meaning of the relevant textual content - and indeed cannot avoid doing so, if they want a compatible meaning - using background frames and information accessible to them. Nothing generally stops a reader from visualizing a character with blue eyes, if the text doesn't describe the character's eyes as brown - although if the character is placed in ist century Judea, that added background information might fill in the likelihood of dark eyes.

To summarize, this parable has become a source story, decontextualized, and projected onto many target situations. But semantic frame analysis will push NT scholars and engaged readers to recontextualize the text and to take care that their appropriations and transpositions are fitting. Studying frames, mental space networks and blending can help us understand the variability as well as constraints on the range of plausible readings.

\section{Narrative Ethics and Characters: Imagining with the Church's Scripture}

The guiding question for this study of characterization in Luke 10:25-37 was: How do 21st century readers construe these NT characters and use them to understand and respond to the parable and the dialog? This study had two additional goals: (1) To use CL methods to notice how Luke constructs characters in a parable; (2) to explain how meanings are evoked, constructed, constrained and opened up via embodied cognition. We have shown how a matched set of CL tools (especially mental space blending and networks, the semantic frames that structure spaces, and the viewpoints shifts that animate narratives) can be used to analyze some features of how characterization works in a text and as readers interpret. The CL finding that readers simulate scenes as they go along provides a key explanatory model for "how" responses are evoked. Embodied experience - including social-relational experience grounds and shapes reading and interpretation at every level. 
Readers are never completely autonomous; they belong to reading and language communities. Reading communities matter because our imaginations are formed and shaped in everyday life together, but also because reading communities tend to share interests and interpretive habits. L.T. Johnson has stressed the importance of "imagining the world that Scripture imagines." 57 Entering that world is not spinning a fantasy. What Johnson describes is exactly what occurs when we read, when a text prompts embodied simulations of the actions and dialog in a scene. That can shape a Bible-reading community's Scriptural imagination and habitual patterns of thought - its character - so that it becomes fluent in Scriptural ways of seeing and being..$^{58}$

This kind of narrative-grounded and -informed moral imagination is embraced by many secular ethicists, as well. The philosopher Mark Johnson, who works with cognitive scientific models, argues:

[O]ur lives ultimately have a narrative structure. It is in sustained narrative, therefore, that we come closest to observing and participating in the reality of life as it is actually experienced and lived. We learn from, and are changed by, such narratives to the extent that we become imaginatively engaged in making fine discrimination of character and in determining what is morally salient in a particular situation. We actually enter into the lives of the characters, and we perform acts of perception, decision, and criticism. We find ourselves judging of a character that she shouldn't have done X, or wishing that he had seen a situation differently than he did. We want to stop the characters and tell them, 'Oh no, don't do that!' ... We explore, we learn, and we are changed by our participation in the fiction that creatively imitates life..$^{59}$

What must I do to inherit eternal life? was the guiding question of our focal text. What must we do? becomes the logical question arising from the story for Luke's first readers and potentially, for any readers who achieve "narrative uptake." The Torah scholar character models for readers how to enter with Jesus into a parable world and let it do its character-building work. What the scholar needed was not a new moral rule or Torah interpretation technique, but a new, embodied way to pay attention and thus to live mercifully. One must

57 L.T. Johnson, "Imagining the World Scripture Imagines," p. 180.

$5^{8}$ E. Shively, "Luke Timothy Johnson and The Spirit of Imagination," Christianity Today (July 2020). https://www.christianitytoday.com/pastors/2020/july-web-exclusives/luke-timothyjohnson-and-spirit-of-imagination.html

59 M. Johnson, Moral Imagination: Implications of Cognitive Science for Ethics (Chicago: University of Chicago Press, 1993), p. 196. 
attend to doing mercy, grounded in the kind of deep inner knowing that moved the Samaritan to act compassionately. This is Jesus' clear imperative: "Go and do likewise!" Readers are implicitly invited to identify with the compassionate character of the parable and emulate him. But the opening question and closing dialog shape the parable's point, expanding its trajectory beyond mere moral rule revision or definitions of "neighbor" or even of "good" character. This parable allows readers to imagine with Luke a way of life lived in the light of the new epoch Jesus announces and inaugurates. 